\title{
Boyun USG eşliğinde perkütan iğne biyopsisi ile tanı alan özofagus kanseri: Olgu sunumu
}

\author{
Esophageal carcinoma diagnosed with percutaneous needle biopsy under neck ultrasound: Case report \\ Işılay NADIR ${ }^{1}$, Ismail KIRBAŞ², Benan KASAPOĞLU ${ }^{3}$, Cansel TÜRKAY ${ }^{1}$ \\ Fatih Üniversitesi Tıp Fakültesi, ${ }^{1}$ Gastroenteroloji Bilim Dalı, ${ }^{2}$ Radyoloji Anabilim Dalı, ${ }^{3}$ Iç Hastalıkları Anabilim Dalı, Ankara
}

\begin{abstract}
Özofagus kanseri dünyada tüm kanserler arasinda 7. sirada yer almaktadır Servikal özofagusa yerleşim \%8 oranındadır. Özofagogastroduedonoskopi eşliğinde alınan biyopsi tanı için altın standarttır. Bu makalede tam obstrüksiyon nedeni ile özofagus lümenini görüntüleyemediğimiz ve konvansiyonel yöntemler ile tanıya ulașamadığımız vakada ultrasonografi eșliğinde perkütan biyopsi ile tanıya ulaştığımız için sunmayı amaçladık.
\end{abstract}

Anahtar kelimeler: Özofagus kanseri, perkütan biyopsi

\section{GİISS}

Özofagus kanseri dünyada tüm kanserler arasında 7. sırada yer almaktadır. Tüm kanserlerin \%1.5-2'sini, gastrointestinal sistem kanserlerinin ise \%5-7'sini oluşturmaktadır. Insidansı bölgelere göre değişmekte olup 30-800 /100.000 arasındadır (1).

Biz bu makalede konvansiyonel tanı yöntemleri ile sonuca ulaşamayıp ultrasonografi (USG) eşliğinde servikal özofagustan perkütan biopsi aldığımız hastayı sunmayı amaçladık.

\section{OLGU SUNUMU}

Elli yaşında kadın hasta 1 aydır katı ve sıvı gıdalara karşı yutma güçlüğü ile kliniğimize başvurdu. 1 ayda 4 kg kaybetmişti. Fizik muayenede patolojik bulgu saptanmadi. Labratuvar incelemede $\mathrm{Hb}: 13.4$ g/dl, Hct: 38.7, MCV: 84.7, PLT: 145000 olarak saptandi. Biyokimyasal parametreler normaldi. Disfajisi olan hastaya özofagogastroduedenoskopi planlandı. Özofagogastroduedenoskopide üst sifinkter hizasında pediatrik endoskopun geçişine izin vermeyen darlık saptandı. Buradan alınan biopsi normal yassı hücreli mukoza olarak rapor edildi. Özofagus pasaj grafisi çekildi. Pasaj grafisinde servikal özofagus proksimal 25 mm'lik segmentinde mukozal paternde maligniteyi düşündürür düzensizlikler ve opak geçişine izin veren ciddi darlık saptandı (Şekil 1). Toraks bilgisayarlı tomografi (BT)'de özofagus başlangıç kesimde kraniokaudal olarak yaklaşık 25 mm'lik segmentte duvar kalınlaşması göstermekte olduğu izlendi. En kalın yerinde özofagus duvarı 6-7 mm ölçüldü (Şekil 2). Endoskopik biyopsileri negatif gelen hasta perkütan biyopsi açısından girişimsel radyolojide USG ile değerlendirildi. USG'de tiroid bezi sol lob posteriorunda izlenen servikal özofagusda annüler
Esophageal carcinoma is the seventh most common carcinoma worldwide. Cervical location is reported at a rate of $8 \%$. The gold standard for diagnosis is biopsy under esophagogastroduodenoscopy. Herein, we report an esophageal carcinoma case that could not be diagnosed with conventional methods but only with percutaneous biopsy under ultrasound.

Key words: Esophageal cancer, percutaneous biopsy

diffüz duvar kalınlaşması dikkati çekti (Şekil 3). Hasta steril şartlarda hazırlandıktan sonra tiroid bezi sol lobu katedilerek 20 G yarı otomatik biyopsi iğnesi ile 3 kez tru-cut biyopsi alındı. İşlemden sonra kompresyonla kanama kontrolü yapıldı. USG ile yapılan kontrolde paraözofageal ya da tiroid bezinde hematom izlenmemesi üzerine işlem sonlandırıldı. Biyopsi materyalinin incelenmesinde squamöz hücreli karsinom ile uyumlu malign epitelyal tümör olarak rapor edildi. Operasyon için hasta cerrahiye yönlendirildi.

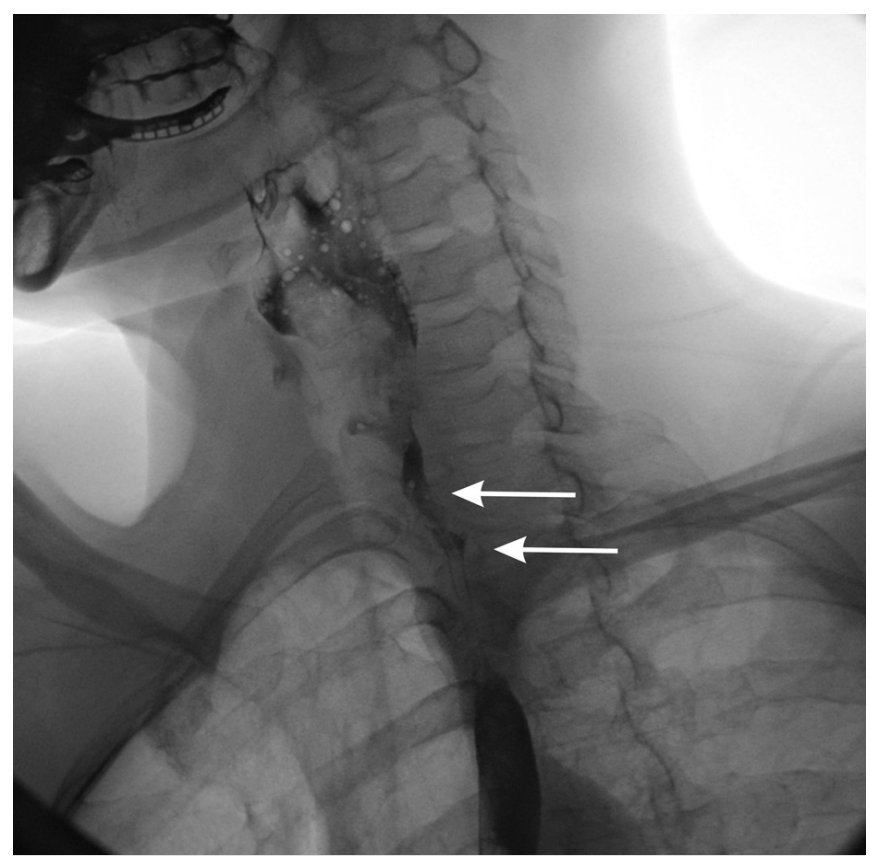

Şekil 1. Özofagus pasaj grafisi: Servikal özefagus proksimal 25 mm'lik segmentinde mukozal paternde maligniteyi düşündürür düzensizlikler. 


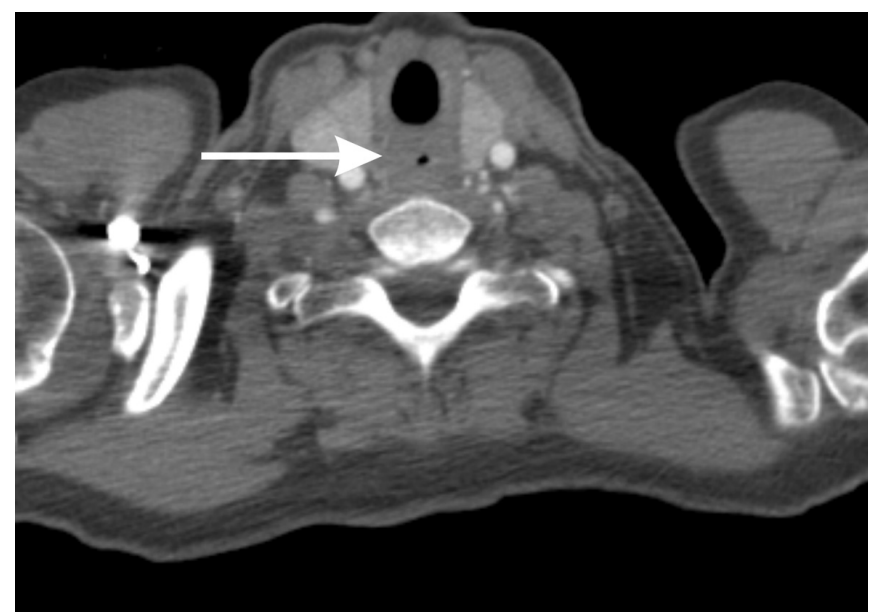

Şekil 2. Toraks BT: Özofagus başlangıç kesimde kraniokaudal olarak yaklaşı 25 mm'lik segmentte duvar kalınlaşması.

\section{TARTISSMA}

Özofagus kanserlerinin \%90-95'ini squamöz cell karsinom oluştururken son ylllarda adenokanser insidansinda artış izlenmektedir. Yerleşim yerine bakıldığında \%8 servikal özofagus, \%3 üst torasik özofagus, \%32 orta torasik özofagus, \%25 alt torasik özofagus ve \%32 oranında kardiyada görülür (2, 3). Bizim vakamız servikal özofagusa yerleşmişti.

Özofagus kanserlerinde en yaygın prezentasyon progressiv disfaji ve kilo kaybıdır. Ayrıca odinofaji, öksürük, ses kısıklığı, horlama, göğüs ağrısı ve melena izlenebilir. Hastalığın yayılımı ve lokal ilerlemesine bağlı farklı semptomlar eşlik edebilir. Fizik muayene sıklıkla normal olmakla beraber servikkal ve supraklavikular LAP saptanabilir (3).

Baryumlu grafi, özofagogastroduedenoskopi (ÖGD), endoskopik ultrasonografi (EUS), BT kullanılan tanı yöntemleridir. Baryumlu grafide dolma defekti izlenebilir. Lezyonun yeri ve birlikte olabilen özofagus patolojileri hakkında bigi verir. Endoskopiste yol göstericidir. Lümen darlığı, trakeözofageal fistül varlığını ortaya koyar. ÖGD özofagus kanseri tanısında altın standattır. Lezyon direkt görülür ve biyopsi alınır. Toraks ve abdomen BT ile lokal invazyonlar adenopatiler, akciğer ve karaciğere olan uzak metastazlar araştırılır. Komşu dokularda invazyonun olduğu T4 tümörlerdeki özgüllüğü \%70-100 arasindadir. Rezektabiliteyi tam olarak ortaya koyamaz, \%52 doğruluğu vardır. En büyük değeri akciğerler ve karaciğere olan uzak metastazların tanınmasıdır. Nükleer manyetik rezonans görüntüleme özofagus kanserinin tanı ve evrelemesine BT’nin üzerine fazla bir şey katmamıştır. Pozitron emisyon tomografinin (PET) lokorejional ve uzak metastazları bulmada-

\section{KAYNAKLAR}

1. Lin SH, Chang YJ. Esophageal cancer: diagnosis and treatment. Chin J Cancer 2010; 29: 843-54

2. Enzinger PC, Mayer RJ. Esophageal Cancer. N Engl J Med 2003; 349; 2241-52.

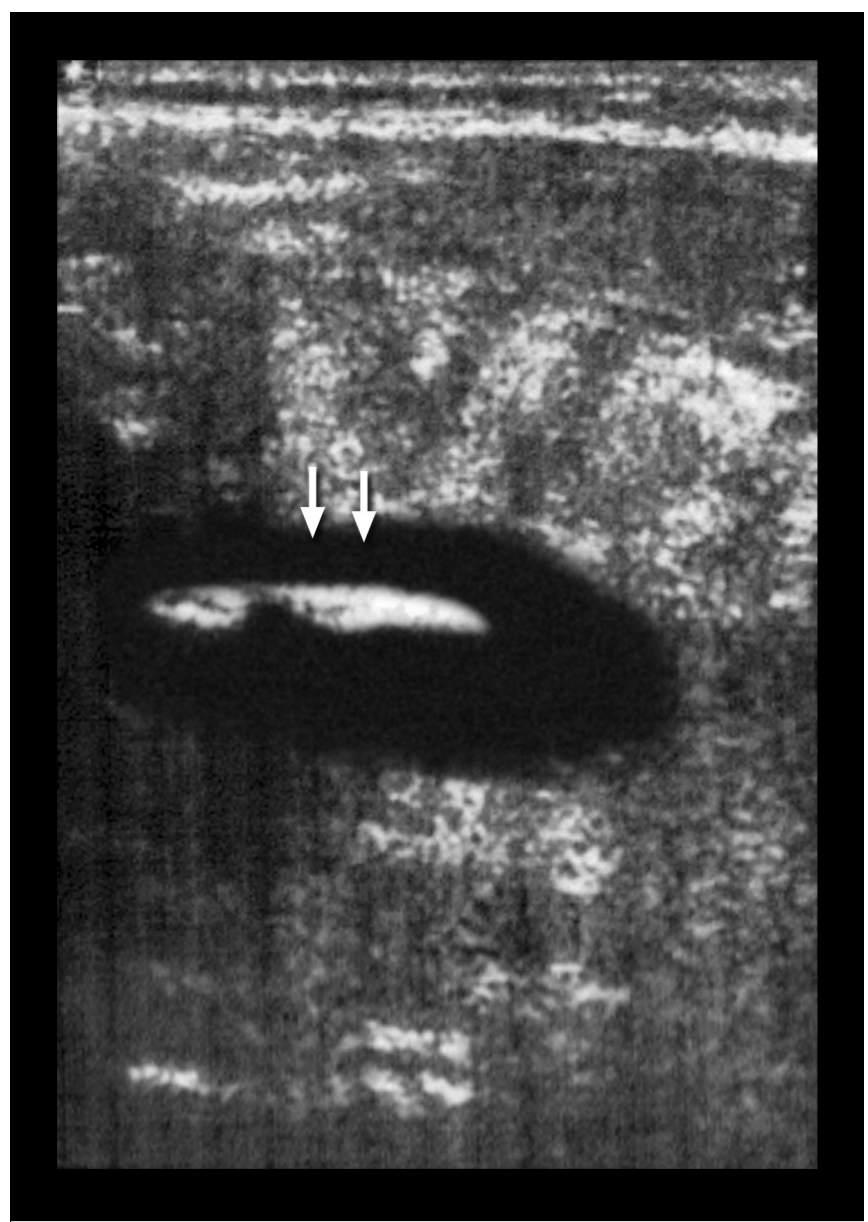

Şekil 3. USG: Tiroid bezi sol lob posteriorunda izlenen servikal özofagusda annüler diffüz duvar kalınlaşması.

ki sonuçları umut vericidir. EUS daha çok tümörün evrelemesinde kullanılmaktadır. EUS tümör invazyonunu belirlemede BT'den daha doğru sonuç verir. BT ile doğruluk \%52 iken EUS ile bu oran \%82'dir. Yine ince iğne aspirasyon biyopsisi ile biyopsi alınarak tanıda da kullanılmaktadır $(1,4)$.

Vakamızda BT'de özofagus duvarı proksimalde $7 \mathrm{~mm}$ olarak normalden kalın izlenmiştir. ÖGD ve endosonografi bizim vakamızda tanıya katkı sağlamamıştır. ÖGD'de lümen izlenmeyip, obstrüksiyonun proksimalinde mukoza düzenlidir. Intramural olduğu düşünülen patolojiden USG eşliğinde perkütan olarak biyopsi alınarak tanıya ulaşılmıştır.

Sonuç olarak vakamızda olduğu gibi servikal intramural özofagus patolojilerinde, tam obstrüksiyon nedeni ile özefagus lümeni konvansiyonel yöntemler ile görüntülenemediğinde USG eşliğinde perkütan biyopsi başvurulacak tanı yöntemi olarak akılda tutulmalıdır.

3. Devesa SS, Blot WJ, Fraumeni JF Jr. Chancing pattern in the incidence of esophageal and gastric carcinoma in the United States. Cancer 1998; 83: 2049-53.

4. Lee RB, Miller JI. Esophagectomy for canser. Surg Clin North Am 1997; 77: 1169-96 